\title{
Pemikiran Anwar Sutoyo tentang Konseling Islam untuk Kesehatan Mental
}

\author{
Agung Saputra ${ }^{1}$, Muzaki $^{2}$ \\ ${ }^{1}$ Program Studi Bimbingan Konseling Islam, Fakultas Ushuluddin Adab dan Dakwah, \\ IAIN Syekh Nurjati Cirebon \\ Email Penulis ${ }^{1}$ : agungsaputra313@gmail.com \\ ${ }^{2}$ Program Studi Bimbingan Konseling Islam, Fakultas Ushuluddin Adab dan Dakwah, \\ IAIN Syekh Nurjati Cirebon \\ Email Penulis 2: kemalzaki66@gmail.com
}

\begin{abstract}
Abstrak
Penelitian ini dilatarbelakangi oleh dampak negatif dari era globalisasi yang membawa dampak pembauran peradaban dan kebudayaan antar bangsa serta membawa dampak bergesernya masyarakat agraris ke masyarakat industri sehingga banyak didapati individu-individu yang melupakan unsur kerohanian yang ada dalam dirinya. Mereka akhirnya terjebak dengan permaslahan duniawi juga paham materialistik dan individualistik yang berpengaruh negatif dalam segi-segi kehidupan manusia. Apabila kondisi seperti ini dibiarkan begitu saja, maka akan membuat manusia kehilangan akal sehatnya, kehilangan nuraninya, kehilangan masa depannya, bahkan membuat hidupnya tidak bermakna dalam artian mengalami kemlaratan dan kesengsaraan jiwa baik di dunia maupun di akhirat kelak. Melihat keadaan seperti ini, akhirnya Anwar Sutoyo memberikan sebuah bantuan berupa layanan konseling Islami sebagai proses pemberian bantuan untuk belajar mengembangkan fitrah dan atau kembali kepada fitrahnya sebagai manusia. Hasil dari penelitian menunjukkan bahwa konseling Islami menurut Anwar Sutoyo adalah sebuah bantuan terhadap individu untuk mengembangkan fitrahnya sebagai manusia dengan cara memberdayakan potensi iman dan akal serta semua kemampuan yang dimiliki individu tersebut. Konseling Islami untuk kesehatan mental individu adalah mencapai kondisi kesadaran spiritual yang tinggi, menanamkan pemahaman mengenai kesadaran diri dan penerimaan diri, membantu memodifikasi tingkah laku, dan membantu memiliki keterampilan sosial serta aksi sosial.
\end{abstract}

Kata Kunci:Konseling Islami; Pemikiran Anwar Sutoyo; Kesehatan Mental.

\section{PENDAHULUAN}

Dalam menghadapi era globalisasi yang membawa dampak pembauran peradaban dan kebudayaan antar bangsa, serta membawa dampak bergesernya masyarakat agraris ke masyarakat industri, banyak didapati individu-individu yang sibuk dengan permasalahan 
duniawi juga paham materialistik dan individualistik yang berpengaruh negatif dalam segisegi kehidupan manusia. Dan kenyataan di era globalisasi sekarang ini, semakin majemuknya kehidupan masyarakat dan sebagainya jelas telah membawa perubahan nilainilai dan norma-norma yang membingungkan, meresahkan, dan menimbulkan problemproblem kehidupan yang pelik, yang tidak sedikit melahirkan sikap-sikap dan perilaku manusia yang destruktif seperti sombong, kikir, zalim, ingkar, mau menang sendiri, dan sebagainya (Amin, 2013, hlm. 24).

Sikap dan perilaku negatif seperti yang diuraikan di atas jelas merupakan bentuk penyimpangan dari perkembangan fitrah beragama manusia yang telah diberikan oleh Tuhan Yang Maha Esa. Dalam kondisi penyimpangan dari perkembangan fitrah yang demikian itu seorang individu akan terlepas hubungannya dengan Tuhan, dan dapat pula mengakibatkan individu tersebut terlepas hubungannya dengan sesama manusia serta alam sekitar, sehingga yang ia lakukan hanya membuat kerusakan baik bagi dirinya sendiri, orang lain, maupun lingkungan di mana ia tinggal (Amin, 2013, hlm. 25).

Dalam kondisi yang terputus hubungan baik dengan Tuhan maupun dengan sesama manusia dan lingkungan, individu tersebut merasa tidak memiliki pegangan yang kuat sebagai pedoman hidupnya. Individu yang demikian itu akhirnya merasa terombangambing dalam kesendiriannya, ia bisa mengalami stres bahkan depresi. Inilah tragedi dunia modern, yang tidak semua mendatangkan keberuntungan dan kebermanfaatan dalam artian yang positif, namun lebih banyak ke arah negatif berupa kemanusiaan modern sebagai kesengsaraan rohaniah. Modernitas pun telah menyeret manusia pada kegersangan spiritual. Menurut Mulyadi (2017, hlm. 21-22) ekses ini merupakan konsekuensi logis dari era globalisasi yang terabaikan, yang pada akhirnya mendatangkan berbagai gangguan kejiwaan.

Fitrah manusia dalam pandangan Anwar Sutoyo (2015, hlm. 23-24) adalah keadaan atau kondisi penciptaan yang terdapat dalam diri manusia yang menjadikannya berpotensi mampu mengenal Tuhannya, karena fitrah tersebut telah ditanamkan oleh Tuhan Sang Maha Pencipta dalam diri setiap insan sejak awal diciptakan. Dengan fitrah tersebut manusia akan cenderung kepada keindahan, kebaikan, pengorbanan, kesetiaan, pemujaan, dan sebagainya. Fitrah manusia yang berkembang secara optimal akan mengantarkan kepada suatu realitas yang Maha Sempurna, tanpa cacat, tanpa batas, dan tanpa akhir, karena sesungguhnya kepada Tuhan mu lah berakhirnya segala sesuatu (Shihab, 2013, hlm. 103-104).

Dengan berpandangan ini, Anwar Sutoyo memperkenalkan konsep konseling Islami sebagai proses pemberian bantuan terhadap individu untuk belajar mengembangkan fitrah dan atau kembali kepada fitrahnya sebagai manusia, dengan cara memberdayakan potensipotensi yang ada pada manusia, seperti iman, akal pikiran, panca indra, dan kekuatankekuatan positif lainnya yang ada pada manusia untuk mengubah corak kehidupannya. Dalam hal ini potensi iman dipandang sebagai inti untuk mendorong dan mengarahkan potensi-potensi lainnya ke arah yang lebih postif, karena jika iman seseorang telah berkembang dan berfungsi dengan baik, maka potensi-potensi yang lainnya pun akan 
berkembang dan berfungsi dengan baik pula. Oleh sebab itulah, dalam pemikiran Anwar Sutoyo (2015, hlm. 22-24) layanan konseling Islami sepatutnya lebih memfokuskan pada pengembangan fitrah manusia berupa iman.

Di sinilah letak salah satu urgensi penggalian konsep konseling Islami sebagai pendekatan dalam upaya membantu masyarakat modern. Seperti yang telah dijelaskan di muka, bahwa bahaya yang dihadapi masyarakat modern saat ini adalah akibat kemajuan ilmu pengetahuan dan teknologi di satu pihak, dan kelengahan manusia dalam menyadari kelemahan-kelemahannya sehingga menjadikannya melupakan unsur kerohanian yang ada dalam dirinya. Di era globalisasi ini, konseling Islami menawarkan cara untuk menjadi dikenal dan didengar. Selain itu, konseling Islami juga merupakan suatu layanan yang mengupayakan mental sehat dan sejahtera, dan juga dapat menuntun manusia kepada hidup yang sakinah, agar hidup merasa tenang dan batin merasa tenteram karena selalu dekat dengan Tuhan (Musnamar, 1992, hlm. 11-12).

Mental sehat pada manusia adalah pengetahuan dan perbuatan yang dapat mengembangkan dan memanfaatkan segala potensi, bakat dan pembawaan yang ada semaksimal mungkin sehingga menciptakan penyesuaian diri antara dirinya sendiri dengan orang lain dan lingkungannya yang berlandaskan atas keimanan dan ketakwaan, yang pada akhirnya membuat hidup lebih bermakna dan bahagia baik di dunia maupun di akhirat (Daradjat, 1990, hlm. 11).

Berdasarkan uraian di atas, maka menunjukkan bahwa keberadaan layanan konseling Islami sangat dibutuhkan oleh masyarakat modern saat ini secara luas untuk menetralkan pengaruh teknologi yang telah menghilangkan kepribadian dan fitrahnya sebagai manusia. Oleh karena itu, kajian mengenai layanan konseling Islami menjadi sangat penting bagi masyarakat modern dalam upaya menggali kembali nlai-nilai keagamaan dan spiritual yang berangsur-angsur mulai dilupakan. Dari sini peneliti tertarik untuk mengkaji pemikiran Anwar Sutoyo mengenai konseling Islami yang dituangkannya ke dalam sebuah buku berjudul "Bimbingan dan Konseling Islami Teori dan Praktik".

Adapun sebab memilih pemikiran Anwar Sutoyo dalam penelitian ini karena beliau seorang sarjana Muslim kontemporer yang bisa dikatakan sangat peduli terhadap perkembangan keilmuan terkait konseling Islami. Selain itu juga beliau merupakan salah satu pakar konseling Islami yang diangkat menjadi pembina dalam Perkumpulan Ahli Bimbingan dan Konseling Islam (PABKI) periode 2017-2022.

\section{METODE PENELITIAN}

Penelitian ini masuk dalam penelitian kualitatif, yaitu suatu penelitian yang mendeskripsikan objek penelitian berupa kata-kata (Kaelan, 2005, hlm. 1). Objek material dalam penelitian ini adalah Anwar Sutoyo dan juga karyanya yang berhubungan dengan konseling Islami. Sedangkan objek formal dalam penelitian ini adalah pemikiran-pemikiran Anwar Sutoyo yang berkaitan dengan konseling Islami.

Penelitian ini termasuk dalam jenis penelitian kepustakaan (library research), yakni penelitian yang kajiannya dilakukan dengan mengumpulkan dan menelaah literatur yang 
terkait dengan tema yang dikaji. Menurut Nazir (2014, hlm. 80) Library research merupakan teknik pengumpulan data dengan cara melakukan penelusuran terhadap bukubuku serta sejumlah tulisan kepustakaan dan menelaahnya. Seluruh data atau referensi bersumber dari literatur kepustakaan, baik buku maupun artikel-artikel yang dimuat dalam berbagai jurnal ilmiah.

Sumber data yang digunakan dalam penelitian ini adalah sumber data primer dan sekunder. Sebagai sumber data primer, peneliti menggunakan buku bimbingan dan konseling Islami karya Anwar Sutoyo dan semua jurnal Anwar Sutoyo yang tersedia di Internet. Sedangkan untuk sumber data sekunder peneliti menggunakan buku bimbingan dan konseling Islam karya Samsul Munir Amin, buku dasar-dasar konseptual bimbingan dan konseling Islami karya Thohari Musnamar dan buku karya Mulyadi yang berjudul Islam dan Kesehatan Mental.

Setelah data terkumpul, langkah selanjutnya adalah mengolah atau menganalisis data. Dalam mengolah data metode yang digunakan adalah interpretasi, artinya menyederhanakan data ke dalam bentuk yang lebih mudah dibaca dan diinterpretasikan untuk mencapai tujuan pokok untuk hal itu, maka penulis merumuskan, mengumpulkan dan memproses data serta membuat analisis dan interpretasi (Nazir, 2014, hlm. 304). Dalam analisis data metode yang digunakan adalah deskriptif dan interpretasi. Metode deskriptif yaitu prosedur pemecahan masalah yang diselidiki dengan menggambarkan atau melukiskan keadaan objek penelitian berdasarkan fakta-fakta yang tampak dan sebagaimana adanya, kemudian data yang sudah terkumpul direpresentasikan harus disertai dengan penafsiran (Nazir, 2014, hlm. 34). Sedangkan interpretasi adalah melayani isi buku untuk setepat mungkin mampu mengungkap arti dan makna uraian yang disajikan (Harahap, 2014, hlm. 49-50). Analisis interpretasi di sini digunakan untuk mengungkap makna yang terkandung dalam buku bimbingan dan konseling Islami karya Anwar Sutoyo.

\section{HASIL DAN PEMBAHASAN}

Secara etimologi istilah konseling berasal dari bahasa latin yaitu "conselium" yang berarti "dengan" atau "bersama" yang dirangkai dengan "menerima" atau "memahami". Sedangkan dalam bahasa Anglo Saxon, istilah konseling berasal dari kata "sellan" yang memiliki arti "menyerahkan" atau "menyampaikan" (Ramayulis dan Mulyadi, 2016, hlm. 110). Sedangkan dalam literatur lain dijelaskan bahwa, istilah konseling berasal dari kata "counseling" yaitu dari kata benda "counsel" yang berarti nasihat (Anwar, 2014, hlm. 2). Sejalan dengan ini, Amin (2013, hlm. 10) menjelaskan bahwa, kata "counseling" adalah kata dalam bentuk masdhar dari "to counsel" yang secara etimologi berarti "to give advice" atau memberikan saran dan nasihat.

Kemudian secara terminologi, para ahli pun beragam pendapat dalam mendefinisikan arti konseling. Menurut Roger, konseling adalah serangkaian hubungan langsung dengan individu yang bertujuan untuk membantu klien dalam mengubah sikap dan tingkah lakunya (Helen, 2012, hlm. 10). Dalam pandangan R.L. Wolberg, konseling merupakan suatu bentuk pemberian bantuan terhadap individu agar individu tersebut lebih mengerti tentang 
dirinya sendiri, sehingga dapat memperbaiki kesulitan yang berhubungan dengan lingkungan atau agar dapat memperbaiki kesulitan penyesuaian (Ramayulis dan Mulyadi, 2016, hlm. 111).

Dewan kehormatan American Counseling Association (ACA) sebagai organisasi terbesar wadah konselor di Amerika (Gladding, 2015, hlm. 6) mendefinisikan konseling sebagai berikut:

"Aplikasi kesehatan mental, prinsip-prinsip psikologi atau perkembangan manusia, melalui intervensi kognitif, afektif, perilaku, atau sistemik; strategi untuk menangani kesejahteraan, pertumbuhan pribadi, atau perkembangan karier, serta kelainan”.

British Association of Counseling (BAC) menegaskan bahwa kata "konseling" mencakup bekerja dengan banyak orang dan hubungan yang mungkin saja bersifat pengembangan diri, dukungan terhadap krisis, psikoterapis, bimbingan atau pemecahan masalah. Tugas konseling menurut BAC adalah memberikan kesempatan kepada "klien" untuk mengeksplorasi, menemukan, dan menjelaskan cara hidup lebih memuaskan dan cerdas dalam menghadapi sesuatu (McLeod, 2015, hlm. 5).

Beberapa ahli di Indonesia juga mendefinisikan konseling secara beragam. Menurut Prayitno, konseling bisa dipahami sebagai proses pemberian bantuan yang dilakukan melalui wawancara oleh seorang ahli (disebut konselor) kepada individu yang sedang mengalami sesuatu masalah (disebut klien) yang bermuara pada teratasinya masalah yang dihadapi oleh klien (Prayitno dan Amti, 2013, hlm. 103). Thohirin mengemukakan bahwa konseling merupakan kontak atau hubungan timbal balik antara dua orang (konselor dan klien) untuk menangani masalah klien, yang didukung oleh keahlian dan dalam suasana yang laras integrasi berdasarkan norma-norma yang berlaku untuk tujuan yang berguna bagi klien.

Dari definisi-definisi para ahli yang telah dijelasan di atas, dapat dilihat bahwa istilah konseling memiliki beberapa makna. Eksistensi interpretasi dan definisi yang kontras mengenai makna konseling tersebut bersumber dari proses yang memunculkan konseling dalam masyarakat modern. Sepanjang abad dua puluh, konseling berkembang dan berubah dengan sangat cepat serta mengandung berbagai tema, penekanan, praktik, dan aliran pemikiran. Terdapat bukti kuat munculnya tren untuk menyatukan berbagai pemikiran dan pendekatan yang ada pada tahun 1980-an, selain itu ada juga yang mencoba mengeksploitasi ide baru serta mengintegrasikannya dengan pendekatan gabungan. Bahkan Karasu telah melaporkan adanya 400 model konseling dan psikoterapi yang muncul di penghujung abad ke dua puluh (Ramayulis dan Mulyadi, 2016, hlm. 111).

Pada dekade delapan puluhan di Indonesia telah muncul suatu pendekatan konseling yang dibangun dari perspektif agama Islam. Usaha publikasi sistematik dalam menggali dan mencari konsep konseling yang berdasarkan pada ajaran Islam ini kemudian dikenal dengan sebutan konseling Islami. Konseling Islami merupakan suatu layanan pemberian bantuan terhadap individu maupun kelompok dalam suatu masyarakatyang mengalami masalah emosi atau psikologi serta tingkah laku yang dibangun berdasarkan pada ajaran 
Islam, yang bersumber dari Al-Qur'an dan As-sunnah (Musnamar, 1992, hlm. 9-10). Secara umum, baik konseling Islami maupun konseling yang diperkenalkan oleh konsep Barat dipandang sebagai sesuatu yang baik, efektif, atau relevan oleh mereka yang hidup sekarang dalam budaya modern. Konseling Islami dan konseling pada umumnya juga sama-sama menyajikan cara untuk menolong manusia dalam menghadapi setiap perubahan, baik perubahan dalam dirinya maupun perubahan sosial.

Namun, secara fundamental terdapat perbedaan antara konseling Islami dengan konseling secara umum. Perbedaan tersebut yaitu konseling secara umum tidak menghubungkan masalah Tuhan dan agama dalam proses konseling, atau dalam layanan konseling ini semua berpusat kepada manusia dan sama sekali tidak berkaitan serta tidak dikaitkan dengan eksistensi Tuhan (antroposentris). Di lain pihak, konseling Islami justru berpusat kepada Tuhan Sang Maha Pencipta, yaitu Allah SWT (teosentris). Setiap langkah dan gerak konseling Islami harus dikaitkan dengan ajaran Islam yang berdasarkan AlQur'an dan Sunnah Nabi. Menurut Thohari Musnamar, meskipun terdapat perbedaan konsep dasar, sudut pandang, dan wawasan antara konseling Islami dengan konseling secara umum, namun itu tidak berarti bahwa konseling Islami menjadi ekslusif menutup diri dari dunia sekelilingnya (Musnamar, 1992, hlm. 18).

Lubis (2015, hlm. 63) mengemukakan bahwa konseling Islami merupakan suatu proses konseling yang berorientasi pada ketenteraman hidup manusia baik di dunia maupun di akhirat. Pencapaian rasa tenteram itu adalah melalui upaya pendekatan diri kepada Allah SWT, karena dengan upaya pendekatan tersebut akan dicapai pula segala perlindungan dari-Nya. Konseling Islami bermakna menuntun konseli ke arah mendekatkan diri kepada Allah SWT melalui amal ibadah yang dilakukan dengan penuh khusyu', sehingga pada gilirannya ia dapat memiliki hati yang sehat dan bersih, jiwa yang tenteram dengan seperangkat sifat-sifat terpuji, serta dapat merasakan hidup tenang dan bahagia untuk pencapaian kehidupan berperilaku dengan akhlak orang Muslim yang sempurna sebagai realisasi dari tuntunan pembawa Islam yaitu Nabi Muhammad SAW (Musari, 2011, hlm. 112).

Integritas eksplisit pendekatan konseling Islami dapat dipandang telah menawarkan sumber daya bagi kesehatan atau kesejahteraan mental yang diperuntukkan bagi mereka yang beriman. Apabila kesuksesan konseling pada umumnya (non-religius) dapat dipandang bergantung pada sumber daya konselor dan klien, maka konseling Islami memperkenalkan tipe sumber daya ketiga, yaitu kekuatan transendental yang bersifat eksternal. Pelayanan konseling Islami adalah usaha untuk mengintegrasikan ide dari konseling dan agama dengan tujuan mengembangkan pendekatan yang baru dan lebih efektif agar dapat meningkatkan iman, Islam dan ihsan bagi setiap individu yang diberi konseling hingga menjadi pribadi yang utuh. Dan pada akhirnya diharapkan dapat hidup bahagia di dunia dan akhirat (Sutoyo, 2015, hlm. 207).

Pribadi yang utuh atau kemantapan kepribadian merupakan kerja fungsi-fungsi yang harmonis atau aspek-aspek kejiwaan yang meliputi kehidupan jasmaniah, psikologis, dan kehidupan sosial budaya. Keutuhan kepribadian dapat diukur melalui derajat keharmonisan 
kesehatan jasmani, psikologis, dan kehidupan ruhaniah. Keutuhan kepribadian (pribadi kaffah) itulah yang menentukan kesehatan dan kebahagiaan jiwa seseorang. Dalam kesehatan mental, pribadi yang utuh akan mampu menyesuaikan diri baik dengan dirinya, orang lain, maupun dengan lingkungannya. Kesehatan mental dan penyesuaian diri yang baik merupakan dasar kebahagiaan bagi seseorang (Amin, 2013, hlm. 142).

Seseorang yang mentalnya sehat akan bertingkah laku serasi, tepat, dan bisa diterima oleh masyarakat pada umumnya. Kemudian sikap hidupnya sesuai dengan norma dan pola hidup kelompok masyarakat, sehingga ada relasi interpersonal dan intersosial yang memuaskan. Sebaliknya, seseorang yang tidak sehat mentalnya secara relatif mereka jauh dari status integrasi, dan memiliki ciri inferior dan superior. Kompleks inferior ini misalnya terdapat pada penderita psikosis, neurosis, dan psikopat (Amin, 2013, hlm. 143). Kesehatan mental secara relatif harmonis atau sangat dekat dengan integritas jasmaniahruhaniah yang ideal. Kehidupan psikisnya stabil, tidak banyak memendam konflik internal, suasana hatinya tenang dan imbang, serta jasmaninya selalu sehat. Mentalitas yang sehat dimanifestasikan dalam gejala; tanpa gangguan batin, dan posisi pribadinya seimbang, baik ke dalam (terhadap diri sendiri), maupun ke luar (terhadap lingkungan sosial).

Dalam pandangan Islam, keharmonisan hubungan manusia terdapat dua hal penting; pertama, hablun minallah, yaitu hubungan antara manusia dengan Tuhan (hubungan vertikal), dan kedua, hablun minannas, yaitu hubungan antara manusia dengan sesama manusia (hubungan horizontal). Dan kedua hubungan tersebut, baik hablun minallah maupun hablun minannas haruslah harmonis, antara keduanya harus sama-sama paralel sehingga terciptalah kedamaian dan ketenangan jiwa dalam diri seorang Muslim. Karena bagi seorang Muslim, tujuan hidupnya adalah untuk mengabdi atau beribadah kepada Allah SWT. Dan kebahagiaan tersebut akan tercapai apabila seorang Muslim mampu memahami, menghayati, dan mengamalkan kenikmatan-kenikmatan yang terdapat dalam beribadah, baik berupa melaksanakan perintah Tuhan maupun meninggalkan laranganNya. Penghayatan bahwa ia berasal dari Allah, untuk Allah, dan kembali berserah diri kepada Allah merupakan inti kehidupan Muslim yang bersifat dinamis. Derajat penghayatan tersebut merupakan ukuran bagi tingkatan kesehatan dan kebahagiaan jiwa seorang Muslim (Amin, 2013).

\section{Pemikiran Anwar Sutoyo tentang Konseling Islami: Suatu Analisis}

Konseling Islami yang diperkenalkan Anwar Sutoyo (2015, hlm. 22) merupakan sebuah bantuan berupa pemberian dorongan dan pendampingan yang diberikan kepada individu agar dapat mengembangkan fitrahnya atau kembali kepada fitrahnya sebagai manusia, dengan cara memberdayakan iman dan akal, serta semua kemampuan yang ada pada setiap individu. Fokus pendekatan konseling Islami ini adalah mengembangkan fitrah iman yang ada pada individu. Melalui studinya, Anwar Sutoyo menyatakan bahwa elemen yang paling fundamental sekaligus terdalam pada pengalaman religius manusia adalah fitrah iman, karena sejak awal diciptakannya, Tuhan telah mengaruniai fitrah berupa iman tersebut, yaitu mengakui keesaan Allah dan tunduk kepada-Nya (Sutoyo, 2015, hlm. 63). 
Menurut Anwar Sutoyo, fitrah iman pada dasarnya adalah pemberi arah, pendorong, dan sekaligus pengendali bagi fungsi fitrah lainnya, seperti fitrah jasmani, rohani, dan nafs yang ada pada manusia. Jika fitrah iman yang ada pada manusia tidak berkembang dan berfungsi dengan baik, maka akan mengakibatkan fitrah jasmani, rohani, dan nafs pada manusia tidak berkembang dan berfungsi secara baik pula. Begitu juga sebaliknya, jika fitrah iman pada setiap manusia ini berkembang dan berfungsi secara baik, tentunya fitrah lainnya juga akan berkembang dan berfungsi ke arah yang lebih baik pula. Dengan kata lain, fitrah iman pada manusia sangat memengaruhi fungsi fitrah lainnya. Seseorang yang mengakui dan memahami bahwa dirinya adalah hamba Allah atau makhluk ciptaan-Nya, tentu akan mengabdi (beribadah) dan tunduk kepada-Nya. Setiap tindakan dan perbuatannya cenderung kepada kebaikan, keindahan, kebijaksanaan, dan selalu berpikir untuk merawat alam ssemesta, bukan merusaknya. Ia sadar bahwa ia berada di dunia ini diberi tugas oleh Allah sebagai khalifah, sehingga dalam menjalani kehidupannya ia tidak menyimpang dari segala tuntunan Tuhan yang menciptakannya.

Dalam membangun gagasannya mengenai layanan konseling Islami, Anwar Sutoyo mendasarkan diri pada pendekatan yang berlandaskan dan berasaskan pada ajaran Islam, atau pendekatan yang bersifat religius dan spiritual. Pada pendekatan model ini, Anwar Sutoyo telah mengeksplorasi serta memodifikasi prinsip konseling yang sudah ada dengan sistem nilai dan perilaku religius, khususnya nilai-nilai yang ada pada agama Islam. Strategi lainnya yang ia lakukan adalah usaha untuk mengintegrasikan ide dari konseling dan agama, karena sejak dahulu kala penyembuhan emosional dan psikologi biasanya dilakukan dalam bingkai religi. Seperti halnya Halmos (dalam McLoed, 2015, hlm. 32), Anwar Sutoyo juga meyakini bahwa teori terapi dan konseling dapat dilihat juga dari sudut pandang keimanan.

Pendekatan konseling Islami Anwar Sutoyo bertujuan membawa manusia berproses mencapai kesehatan jiwa optimal yang membutuhkan dukungan dari nilai-nilai keyakinan, ketaatan, kesederhanaan, keuletan, berjuang, bersyukur, pasrah, cinta tanpa pamrih, kerendahanhati, dan lain-lain, yang semua justru bersumber pada ajaran agama Islam. Nilai-nilai tersebut seperti nilai iman, Islam, dan ihsan. Pendekatan semacam ini dipandang akan menawarkan sumber daya bagi kesehatan atau kesejahteraan mental yang tidak diperuntukkan bagi mereka yang tidak beriman. Apabila konseling non-religius dapat dipandang bergantung pada sumber daya konselor dan klien, maka konseling Islami ini memperkenalkan tipe sumber daya ketiga, yaitu kekuatan transendental yang bersifat eksternal.

Dengan berpegang teguh pada nilai-nilai yang muncul melalui proses konseling Islami, seperti nilai iman, Islam, dan ihsan, maka manusia dapat mengembangkan fitrahnya secara maksimal ke semua dimensinya. Atau dengan meminjam istilah Maslow, manusia tersebut akan mencapai aktualisasi diri. Aktualisasi diri dalam sudut pandang konseling Islami baru dapat dicapai secara benar oleh manusia setelah menginternalisasikan nilai-nilai iman, Islam, dan ihsan dalam kehidupannya. Aktualisasi diri tersebut tidak boleh dibiarkan berkembang tanpa arah, apalagi berkembang hanya untuk memenuhi kepentingan diri 
sendiri dan kesenangan dunia semata. Aktualisasi diri yang baik harus sinkron serta sejalan dengan realisasi hakikat dan tujuan hidup manusia di dunia.

Sesuai pembahasan sebelumnya memang dapat dimengerti apabila konsep layanan konseling Islami Anwar Sutoyo bertitik tolak dari suatu pandangan yang estetis sampai yang falsafi tentang hakikat manusia menurut perspektif Al-Qur'an. Manusia dalam AlQur'an, menurut Anwar Sutoyo merupakan makhluk ciptaan Allah (hamba Allah) yang sengaja diciptakan untuk menjadi khalifah di muka bumi sekaligus untuk beribadah (tunduk) kepada-Nya. Al-Qur'an menjelaskan bahwa manusia diciptakan dari dua unsur pokok, yaitu dari tanah (dimensi material) dan embusan roh (dimensi spiritual). Kedua unsur tersebut merupakan satu kesatuan yang tidak dapat dipisahkan. Bila dipisah, maka ia bukan lagi manusia.

Memahami manusia dalam perspektif Al-Qur'an, menurut Anwar Sutoyo justru menunjukkan bahwa sesuai kodratnya pertumbuhan manusia tidak hanya satu arah saja seperti mengejar kebutuhan fisik (material) semata, tetapi juga butuh reslasi dengan sesama yang baik untuk memenuhi kebutuhan rohani (spiritual). Fokus pada kehidupan untuk mengejar kesenangan dunia semata bukan gambaran manusia utuh (kaffah) yang dipikirkan Anwar Sutoyo. Manusia yang baik dalam pemikiran Anwar Sutoyo adalah manusia yang mengambil tanggung jawab dalam hidupnya untuk mengembangkan fitrahnya sebagai manusia semaksimal mungkin demi kebaikannya dan kebaikan lingkungannya, agar tugas kekhalifahannya di muka bumi sesuai dengan tuntunan Tuhan Yang Maha Pencipta.

Dengan berpandangan semacam itu, Anwar Sutoyo menyatakan bahwa untuk menjadi manusia yang utuh (kaffah), hal yang paling pertama dan utama perlu disadari adalah bahwa manusia memerlukan suatu pegangan dalam hidupnya. Pegangan tersebut khususnya dalam memberi landasan perlunya nilai-nilai yang mampu membimbing manusia bertumbuh menuju eksistensi diri sebagai makhluk ciptaan Tuhan. Eksistensi diri yang mampu membawa kesadaran berproses menuju kebijaksanaan tertinggi yang dapat dicapainya. Sumber nilai-nilai yang mendalam seperti itu hanya dapat diperoleh dari agama. Manusia memang bisa berfilsafat mengembangkan suatu nilai tertentu, tetapi keterbatasan akal budi manusia membuatnya tidak mampu memberikan landasan yang kokoh bagi nilai-nilai luhur dan mulia.

Bahkan Al-Kindi (dalam Rahman, 2017, hlm. 55) pernah mengatakan bahwa, meskipun agama dan filsafat sama-sama berusaha mencari kebenaran, tetapi kebenaran filsafat bersifat tidak pasti, sedangkan kebenaran agama bersifat pasti. Bagi Anwar Sutoyo, nilai-nilai tertinggi tidak dapat bersumber dari manusia sebagai makhluk yang fana, tetapi hanya dapat bersumber dari realitas yang berada di luar dan jauh melampaui manusia itu sendiri, dan Dia adalah Tuhan. Dengan demikian, penghayatan religius yang mendalam akan menjadi sarana terbaik bagi manusia untuk menanamkan nilai-nilai yang dapat dijadikan pegangan hidup manusia di dunia, yang pada akhirnya dapat menyelamatkannya pula kelak di akhirat. 


\section{Pemikiran Anwar Sutoyo tentang Konseling Islami untuk Kesehatan Mental}

Konseling Islami yang diajukan Anwar Sutoyo merupakan sebuah pendekatan dalam upaya membantu individu untuk belajar mengembangkan serta meningkatkan nilai-nilai yang mampu membawanya untuk mencapai kodratnya yang tertinggi, yang luhur dan mulia sebagai manusia. Nilai-nilai tersebut dianggap mampu membawa kesadaran berproses menuju kebijaksanaan tertinggi yang dapat dicapai oleh setiap manusia. Dan nilai-nilai yang dimaksud adalah iman, Islam, dan ihsan. Melalui pendekatan konseling Islami ini nilai-nilai seperti iman, Islam, dan ihsan mulai dikembangkan dalam diri setiap individu agar dapat memberikan arah dalam kehidupannya baik di dunia maupun di akhirat.

Pendalaman dan penghayatan nilai iman, Islam, dan ihsan pada setiap individu akan mengarahkan ke arah hidup yang benar sesuai dengan fitrahnya sebagai manusia dan sesuai dengan tujuan hidupnya sebagai manusia. Kesadaran akan fitrah dirinya sebagai manusia merupakan langkah awal yang sangat penting menuju solusi terhadap berbagai masalah kehidupan yang dialami manusia. Di mana esensi fitrah manusia sebagai hamba Allah adalah beriman kepada-Nya, yaitu mengakui keesaan Allah dan tunduk kepada-Nya. Sebagaimana dijelaskan dalam QS. Al-A'raf: 172 bahwa pengakuan manusia bahwa Allah adalah Tuhannya dan hanya Dia yang berhak disembah itu terjadi sejak awal diciptakannya manusia, di mana manusia masih berbentuk sel di dalam tulang sulbi orang tuanya (Sutoyo, 2015, hlm. 63).

Menurut pandangan Anwar Sutoyo, dalam fitrah iman ini telah tercakup pula nilai Islam dan ihsan pada diri manusia. Artinya, setelah manusia mengakui dengan keteguhan hati dan mengucapkan dengan lisan bahwa tiada Tuhan selain Allah (keesaan Allah), maka ia diharuskan mengamalkannya dengan segenap anggota badan dan perbuatan tentang pengakuannya tersebut terhadap adanya Allah SWT (Sutoyo, 2015, hlm. 121).

Oleh sebab itulah, konseling Islami Anwar Sutoyo yang bertujuan membawa manusia berproses untuk mencapai fitrahnya secara optimal memandang fitrah iman pada manusia ini sebagai inti dan dasar yang harus dikembangkan dalam proses konseling. Karena dengan fitrah iman ini manusia akan selalu terdorong untuk melakukan amal saleh, yaitu segala pikiran dan perbuatannya cenderung kepada hal-hal yang baik menurut Allah dan rasul-Nya, sehingga segala tindakan yang diperbuatnya akan bermanfaat bagi dirinya sendiri dan bagi manusia lainnya. Dengan demikian, proses layanan konseling Islami yang ditawarkan Anwar Sutoyo ini dapat membawa manusia ke arah martabat yang luhur sesuai dengan fitrahnya yang tertinggi. Proses pencapaian fitrah tertinggi pada manusia juga sekaligus merupakan proses pencapaian kesehatan mental yang optimal.

Proses manusia menuju fitrah dan kembali pada fitrahnya dalam layanan konseling Islami dengan proses pertumbuhan kesehatan mental adalah dua proses yang saling memengaruhi. Dengan kata lain, proses layanan konseling Islami yang menekankan pada pengembangan nilai-nilai iman, Islam, dan ihsan pada individu untuk menuju fitrahnya sebagai manusia yang benar, tentu juga akan mendukung proses kesehatan mental pada kehidupan individu tersebut. Makin optimal seseorang dalam mengembangkan fitrah iman yang ada pada dirinya, maka secara otomatis akan semakin meningkat pula pemahamannya 
tentang kesehatan jiwa. Karena jika fitrah iman yang ada pada seseorang itu dapat berkembang dan berfungsi dengan baik, secara bersamaan fitrah-fitrah yang lainnya seperti fitrah jasmani, rohani, dan nafs pun akan berkembang dan berfungsi dengan baik pula pada dirinya.

Berkembang dan berfungsinya fitrah iman pada kehidupan seseorang dapat dilihat ketika ia mampu melaksanakan perintah Tuhannya secara keseluruhan, ia tidak mengamalkan sebagian dan meninggalkan sebagian yang lain, serta ia tidak mudah dijerumuskan oleh hawa nafsunya. Seseorang yang fitrah imannya telah berkembang dengan baik, maka ia tidak hanya menyatakan beriman saja, tetapi lebih dari itu ia adalah seorang manusia yang dengan imannya mampu memberi arah, mendorong, dan mengendalikan fitrah jasmani, rohani, dan nafs yang ada padanya, sehingga semua pikiran dan tindakannya ada dalam koridor kedamaian. Ia damai dengan dirinya, keluarganya, seluruh manusia, tumbuh-tumbuhan, serta alam raya (Sutoyo, 2015, hlm. 125).

Dari penjelasan di atas dapat dikatakan bahwa, proses menuju fitrah manusia dalam layanan konseling Islami ini sangat berpengaruh pula pada peningkatan kesadaran terhadap kesehatan mental seseorang. Ini sesuai dengan apa yang dikatakan Zakiah Daradjat mengenai kesehatan mental manusia. Menurutnya (dalam Hasneli, 2014, hlm. 4) bahwa kesehatan mental adalah terwujudnya keserasian dan keharmonisan yang sungguh-sungguh antara fungsi jasmani, rohani, dan nafs pada seseorang, sehingga mampu menciptakan penyesuaian diri antara manusia dengan dirinya sendiri serta lingkungannya berlandaskan keimanan dan ketaqwaannya, agar mencapai hidup yang bermakna dan bahagia di dunia dan di akhirat.

Dengan demikian, untuk mencapai pribadi yang optimal, manusia perlu menjalani hidup dengan selalu menjaga keselarasan dan keseimbangan antara kedua proses ini, yaitu proses pengembangan fitrah iman dan proses kesehatan mental pada manusia. Penghayatan fitrah iman yang makin dalam pada seseorang tentunya akan berdampak pula pada peningkatan kesehatan mentalnya. Pada hakikatnya, implementasi nilai-nilai yang ada pada proses layanan konseling Islami seperti iman, Islam, dan ihsan dalam kesehatan mental seseorang, secara menyeluruh merupakan sebuah realisasi yang berkaitan untuk membawa manusia ke arah martabat yang luhur sesuai kodratnya yang tertinggi, yaitu menjadi pribadi yang utuh (kaffah) yang sesuai dengan fitrah dan tujuan hidupnya sebagai manusia.

Berikut nilai-nilai iman, Islam dan ihsan yang ada pada layanan konseling Islami Anwar Sutoyo bagi pengembangan kesehatan mental seseorang.

\section{Membantu Seseorang Mencapai Kondisi Kesadaran Spiritual yang Lebih Tinggi}

Semakin optimal manusia mengembangkan potensi imannya maka dengan sendirinya akan berpengaruh juga dalam meningkatkan kesadaran spiritualitasnya. Kesadaran spiritualitas adalah sumber motivasi dan emosi pencarian seseorang yang berkenaan dengan hubungannya dengan Tuhannya. Manusia sebagai makhluk rohaniah akan selalu berusaha agar hidupnya bermakna dan mempunyai arti. Pemberian makna pada hidup yang tertinggi adalah pengabdian dalam hubungan dengan Sang Penciptanya, yaitu Tuhan Yang Maha Kuasa. Manusia harus mempunyai kesadaran 
yang kuat mengenai hubungannya dengan Tuhan untuk dapat menyelesaikan dengan baik setiap kesulitan, ketakutan, dan setiap konflik yang dialaminya dalam kehidupan sehari-hari (Amin, 2013, hlm. 158).

Peningkatan dan pengembangan fitrah iman dalam proses konseling Islami jelas sangat berpengaruh terhadap peningkatan pemahaman spiritualitas pada seseorang. Pendalaman dan penghayatan spiritualitas pada seseorang akan memberikan landasan baginya untuk lebih mampu berjuang menjalani kehidupan dengan suka cita dan rasa aman. Pencapaian kesadaran spiritualitas tersebut akan mudah didapat ketika seseorang aktif mendekatkan diri kepada Tuhan, karena kebahagiaan dan ketenangan jiwa yang sebenar-benarnya hanya akan tercapai jika manusia telah menemukan hubungan dan kedekatannya dengan Tuhan. Dengan demikian, penghayatan kesadaran spiritualitas yang semakin tinggi pada seseorang tentunya akan berdampak pula pada peningkatan kesehatan mentalnya.

\section{Membantu Menanamkan Pemahaman kepada Seseorang Mengenai Kesadaran Diri dan Penerimaan Diri}

Pengetahuan mengenai diri sendiri yang meliputi kesadaran diri dan penerimaan terhadap diri sendiri merupakan salah satu ukuran kematangan kepribadian seseorang. Kesadaran diri yang dimiliki seseorang seharusnya mampu membawanya kepada pemahaman tertinggi tentang hakikatnya sebagai manusia. Dari kesadaran terhadap diri sendiri ini seseorang akan menyadari bahwa dirinya adalah makhluk ciptaan Tuhan. Ia ada di dunia bukan kebetulan atau muncul dengan sendirinya, tetapi ada yang mengadakan dan menciptakannya, yaitu Tuhan Yang Maha Kuasa. Tuhan langit dan bumi beserta segala isinya. Dengan kesadaran seperti ini, seseorang akan meyakini bahwa segala sesuatu di dunia ini tidak satupun yang bersifat kebetulan. Semuanya berada dalam pengaturan Tuhan Sang Maha Pencipta (Kuhsari, 2012, hlm. 151).

Seseorang yang telah mencapai kesadaran diri seperti di atas, tentu akan mengantarkannya kepada pemahaman mengenai penerimaan diri. Menurut McLeod (2015, hlm. 13) penerimaan diri merupakan pengembangan sikap positif terhadap diri, yang ditandai oleh kemampuan menjelaskan pengalaman yang selalu menjadi subjek kritik diri dan penolakan.Kebanyakan tekanan jiwa yang dialami seseorang dipicu dari sejumlah faktor, dan salah satunya adalah kurangnya pemahaman terhadap penerimaan diri tersebut, sehingga menimbulkan sikap penyesalan secara berlebihan yang berakibat stres dan frustasi. Seseorang yang beriman kepada takdir Tuhan akan menghadapi semua permasalahannya dengan tenang, ia akan menganggap setiap keberhasilan dan kegagalannya sebagai takdir Tuhan. Apa yang dipandang baik oleh manusia belum tentu baik di hadapan-Nya, demikian pun sebaliknya. Dengan begitu ia akan menerima dengan ikhlas atas apa yang diberikan Tuhan kepada dirinya. Kegagalan dan keberhasilan baginya sama saja, sama-sama ada hikmahnya. Penerimaan diri seperti ini akan memandang kegagalan sebagai kritik diri untuk lebih berhati-hati agar menjadi lebih baik. Dan keberhasilan baginya merupakan karunia yang diberikan Tuhan atas 
ikhtiar dan usahanya, sehingga ia akan selalu bersyukur dalam kondisi dan keadaan apapun (Sutoyo, 2015, hlm. 162).

\section{Membantu Memodifikasi Perubahan Tingkah Laku}

Salah satu cara menghadapi tekanan jiwa terhadap seseorang adalah dengan menciptakan perubahan besar dalam batin dan jiwanya di bawah naungan iman, agar ia kembali kepada fitrahnya yang paling luhur dan mulia sebagai manusia ciptaan Tuhan. Dengan perubahan ini menjadikan seseorang memperoleh kekuatan yang tak pernah terbayangkan sebelumnya. Melalui kekuatan inilah, seseorang akan mampu mengontrol tingkah laku dan aktivitasnya, sehingga setiap perbuatan serta tindakannya terkendali dan terarah. Ia pun akan mampu mengetahui kelemahan pribadinya, mana yang untuk dihilangkan, diperbaiki, dikembangkan, atau diubah.

Perubahan dalam batin dan jiwa seseorang yang berlandaskan atas nilai-nilai dan kekuatan iman, secara sendirinya akan mempengaruhi perilaku yang bersifat jasmaniah pada orang tersebut. Sebab itulah, kekuatan serta kemampuan dalam jiwa seseorang perlu dikembangkan dan diarahkan semaksimal mungkin, karena jiwa yang ada pada seseorang mengandung nilai-nilai, baik positif maupun negatif. Paling tidak, jiwa manusia mengandung hawa nafsu yang mendorong manusia kepada kebinasaan. Untuk mengembangkan kemampuan jiwa seseorang dibutuhkan nilai-nilai yang sedemikian jelas dan kuat. Tanpa kejelasan dan kekuatan, ia tidak akan menghasilkan sesuatu perubahan pada sisi jasmani seseorang. Dengan kata lain, yang mengendalikan dan mengarahkan kekuatan jiwa manusia sehingga menghasilakn aktivitas dan perilaku manusia adalah nilai-nilai yang dianutnya. Nilai-nilai tersebut memotivasi gerak langkahnya, yang kemudian melahirkan akhlak baik atau buruk pada seseorang (Shihab, 2013, hlm. 483).

Setiap langkah dalam pengembangan nilai-nilai iman (tauhid) dalam jiwa manusia akan menghasilkan suatu perubahan positif berupa kemajuan dan kematangan berpikir, kedewasaan emosional, kemantapan sikap, dan pengendalian tingkah laku seseorang. Nilai-nilai yang mendorong pengamalan dan aktivitas, serta yang dirasakan oleh seseorang memengaruhi dan menguasai seluruh jiwa raganya harus dikembangkan dengan baik, sehingga nilai-nilai itu dapat melahirkan akhlak dan perilaku yang sesuai dengan makna hidupnya. Pola tingkah laku yang maladaptif atau merusak dalam diri seseorang dapat diubah atau dimodifikasi dengan menanamkan nilai-nilai yang mulia pada jiwanya. Semakin luhur dan tinggi suatu nilai yang dikembangkan pada seseorang, maka semakin luhur dan tinggi pula nilai yang dicapainya. Sebaliknya, semakin terbatas ia, semakin terbatas pula pencapaiannya (Shihab, 2013, hlm. 388).

\section{Membantu Memiliki Keterampilan Sosial dan Aksi Sosial}

Perubahan ke arah yang positif dapat terlaksana akibat pemahaman dan penghayatan seseorang terhadap nilai-nilai Al-Qur'an, serta kemampuan memanfaatkan dan menerapkan nilai-nilai Al-Qur'an tersebut pada kehidupan ssehari-hari. Al-Qur'an dalam hal ini tidak menjadikan dirinya sebagai alternatif pengganti usaha manusiawi, tetapi sebagai pendorong dan pemandu, demi berperannya manusia secara positif dalam 
bidang-bidang kehidupan (Sutoyo, 2015, hlm. 133). Perubahan positif yang terjadi pada diri seseorang harus diwujudkan dalam suatu landasan yang kokoh serta berkaitan erat dengannya, sehingga perubahan yang terjadi pada dirinya itu menciptakan arus, gelombang, atau paling sedikit riak yang menyentuh orang lain (Shihab, 2013, hlm. 386).

Dapat dikatakan bahwa untuk mencapai kedudukannya yang tertinggi manusia harus mengerjakan suatu amal saleh. Dalam mengerjakan amal saleh tersebut, tentu saja dibutuhkan hubungan antara manusia dengan manusia lainnya, karena dalam arti umum amal saleh dirumuskan sebagai semua perbuatan lahir maupun batin yang berakibat pada hal-hal yang positif atau bermanfaat baik bagi dirinya dan juga bagi orang lain (Sutoyo, 2015, hlm. 139). Bahkan secara kodrati, manusia hidup memerlukan bantuan manusia lainnya, sebab manusia akan menjadi manusia manakala bisa memberikan manfaat bagi manusia lain dan lingkungannya.

\section{SIMPULAN}

Pemikiran Anwar Sutoyo mengenai konseling Islami ini bertitik tolak dari suatu pandangannya tentang hakikat dan fitrah manusia dalam perspektif kitab suci umat Islam, yaitu Al-Qur'an. Dengan begitu, dalam membangun gagasannya terhadap layanan konseling Islami lebih kepada suatu pendekatan yang bersifat religius dan spiritual.Pemikiran Anwar Sutoyo berkenaan dengan konseling Islami terhadap pengembangan kesehatan mental individu antara lain: 1) membantu individu mencapai kondisi kesadaran spiritual yang lebih tinggi, yaitu memberikan pencerahan terhadap kesadaran individu untuk mengenali sumber motivasi dan emosi yang berkenaan dengan kekuatan transendental, pemahaman terhadap makna hidup yang tertinggi adalah pengabdian dalam hubungannya dengan Sang Penciptanya, yaitu Tuhan Yang Maha Esa; 2) membantu menanamkan pemahaman kepada individu mengenai kesadaran diri dan penerimaan diri, karena dengan penghayatan mengenai kesadaran diri yang semakin dalam akan berdampak pada penerimaan diri terhadap diri sendiri yang optimal; 3) membantu memodifikasi perubahan tingkah laku, maksudnya adalah menciptakan perubahan besar dalam batin dan jiwa seorang individu di bawah naungan nilai-nilai yang luhur, seperti iman, Islam, dan ihsan; dan 4) membantu memiliki keterampilan sosial dan aksi sosial, yaitu memberikan pemahaman tentang memiliki dan menguasai keterampilan sosial dan interpersonal, serta mengkontribusikan kebaikan bersama (collective good).

\section{DAFTAR PUSTAKA}

Amin, Samsul Munir. (2013). Bimbingan dan Konseling Islam. Jakarta: Amzah.

Anwar, M. Fuad. (2014). Landasan Bimbingan dan Konseling Islam. Yogyakarta: Depublish.

Daradjat, Zakiah. (1990). Kesehatan Mental. Jakarta: CV Haji Mas Agung. 
Gladding, Samuel T. (2015). Counseling a Comprehensive Profession. Alih bahasa oleh P.M. Winarno. Konseling Profesi yang Menyeluruh. Jakarta: Indeks.

Harahap, Syahrin. (2014). Metodologi Studi Tokoh dan Penulisan Biografi. Jakarta: Prenada.

Hasneli. (2014). Kesehatan Mental dalam Pandangan Islam. Padang: Haifa Press.

Helen. (2012). Bimbingan dan Konseling. Jakarta: Amzah.

Lubis, Syaiful Akhyar. (2015). Konseling Islami: dalam Komunitas Pesantren. Bandung: Cita Pustaka Media.

Kaelan. (2005). Metode Penelitian Kualitatif. Yogyakarta: Paradigma.

Kuhsari, Ishaq Husaini. (2012). Negoh-e Qur'oni be Fesyor-e Ravoni. Alih bahasa oleh Muhammad Habibi Amrullah. Al-Qur'an dan Tekanan Jiwa. Jakarta: Sadra Press.

McLeod, John. (2015). An Introduction to Counseling. Alih bahasa oleh A.K. Anwar. Pengantar Konseling: Teori dan Studi Kasus. Jakarta: Kencana.

Musari. (2011). Bimbingan dan Konseling. Bandung: Pustaka Diamond.

Musnamar, Thohari. (1992). Dasar-dasar Konseptual Bimbingan dan Konseling Islami. Yogyakarta: UII Press.

Nazir, Moh. (2014). Metode Penelitian. Jakarta: Ghalia Indonesia.

Prayitno dan Erman Amti. (2013). Dasar-dasar Bimbingan dan Konseling. Jakarta: Rineka Cipta.

Rahman, Agus Abdul. (2017). Sejarah Psikologi: Dari Klasik Hingga Modern. Jakarta: Raja Grafindo Persada.

Ramayulis dan Mulyadi. (2016). Bimbingan dan Konseling Islam di Madrasah dan Sekolah. Jakarta: Kalam Mulia.

Shihab, Quraish. (2013). Membumikan Al-Qur'an: Fungsi dan Peran Wahyu dalam Kehidupan Masyarakat. Bandung: Mizan.

Shihab, Quraish. (2013). Secercah Cahaya Ilahi: Hidup Bersama Al-Qur'an. Bandung: Mizan.

Sutoyo, Anwar. (2015). Bimbingan dan Konseling Islami: Teori dan Praktik. Yogyakarta: Pustaka Pelajar. 
110 | Saputra \& Muzaki - Pemikiran Anwar Sutoyo ...

Sutoyo, Anwar. (2015). Manusia dalam Perspektif Al-Qur'an. Yogyakarta: Pustaka Pelajar. 